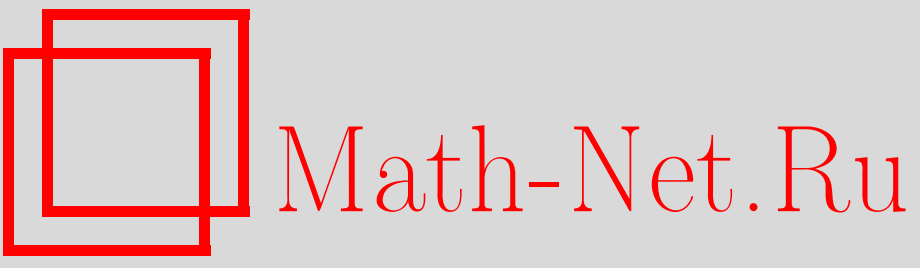

От правления Московского математического общества, УМН, 1996, том 51, выпуск 5, 239

DOI: https://doi.org/10.4213/rm6818

Использование Общероссийского математического портала Math-Net.Ru подразумевает, что вы прочитали и согласны с пользовательским соглашением

http://www.mathnet.ru/rus/agreement

Параметры загрузки:

IP : 18.234 .156 .22

26 апреля 2023 г., 16:58:20 


\section{ОТ ПРАВЛЕНИЯ МОСКОВСКОГО МАТЕМАТИЧЕСКОГО ОБЩЕСТВА}

3 сентября 1996 г. состоялось Распорядительное собрание Московского Математического Общества. С отчетным докладом выступил Президент ММО С. П. Новиков.

Состоялись выборы нового состава Правления ММО. Президентом ММО избран В.И. Арнольд, вице-президентами - А. А. Болибрух и Ю. С. Ильяшенко, редактором трудов ММО - О.А. Олейник, казначеем - А. В. Михалев, библиотекарем - В. М. Тихомиров, ответственным за краткие сообшения ММО - В. М. Бухштабер, ученым секретарем - С. М. Гусейн-Заде.

Членами правления ММО избраны А.А. Аграчев, Д. В. Аносов, В. А. Васильев, Э.Б. Винберг, И.М. Гельфанд, А.Г. Костюченко, Р.А. Минлос, А.И. Нейштадт, С. П. Новиков, В.И. Оселедец, Н. Х. Розов, Я.Г. Синай, А.Г. Хованский, Б. Л. Фейгин, А.Н. Ширяев.

Членами ревизионной комиссии ММО избраны В.А. Голубева, А.Д. Мышкис, Е.Г. Скляренко, Ю. М. Смирнов, А. В. Фурсиков.

Почетными членами ММО избраны Дж. Бирман (J. Birman), A. Вейль (A. Weil), И. Зингер (I. Singer) и Ю. С. Осипов. 